\title{
Qualitative Land Suitability Evaluation for Growth of Wheat in Northeast of Iran
}

\author{
${ }^{1}$ Shahram Ashraf, ${ }^{3}$ Ruzana Munokyan, ${ }^{2}$ Behnam Normohammadan and ${ }^{4}$ Alireza Babaei \\ ${ }^{1}$ Department of Soil Science, ${ }^{2}$ Department of Chemistry, \\ Islamic Azad University, Damghan Branch, Damghan, Iran \\ ${ }^{3}$ Faculty of Agriculture, Armenian State Agrarian University, Yerevan, Armenia \\ ${ }^{4}$ Agriculture Education Center of Mazandaran, \\ Institute of Scientific Applied Higher Education of Jihad-E-Agriculture, \\ P.O. Box 48175-545, Sari, Iran
}

\begin{abstract}
Wheat is one the major crop in Damghan plain where placed in North of Iran. Detailed soil spatial information is required for many environmental modeling and land management application FAO guidelines on the land evaluation system were widely used for the land suitability. This system was based on matching between land qualities/characteristics and crop requirements. In this study, land suitability evaluation based on FAO has been determined for wheat irrigated area about 3400 ha in the South of Damghan plains. In order to have more reliable soil data, particularity to control the old soil map of the area, a new soil survey was carried out in the area. These soils were classified based on semi details studies with 3 physiographic units and four map units and two order Aridisols and Entisols. Climatic data were used from Damghan meteorological and synoptic stations to climate evaluation for wheat. Respect to soil severe limitations in the study area, the results of map units as the assessment methods include the storie, square root and the number of simple constraints was the same as N2 with permanent unsuitable.
\end{abstract}

Key words: Land evaluation, wheat, plain Damghan, square root, Simple limitation method, soil map

\section{INTRODUCTION}

Detailed soil spatial information is required for many environmental modeling and land management application (Burrough, 1996). The most serious limitation of the current soil survey include uncertainly regarding presence of inclusions, lack of mechanism to quantify spatial variability and the assignment of properties derived from typical pedons to the entire map unit regardless of the inherent spatial and temporal variability of field soils (Breeuwsma et al ., 1986).

Wheat is one the major crops in Damghan plain. Its production is an important source of income for many farmers. FAO guidelines on the land evaluation system (FAO, 1976, 1985) were widely used for the land suitability. This system was based on matching between land qualities/characteristics and crop requirements. Physical land evaluation methods (Sys et al., 1991) are crucial for evaluating potentials and constraints of land for intended land use. Physical resources such as soil, climate, hydrology and topography are evaluated. Different technical procedures were used for physical land evaluation ranging from simple methods based on expert knowledge to more complex methods based on simulation models. The study area, chosen is Damghan plain in Iran at approximately $54^{\circ} 20^{\prime}-54^{\circ} 28^{\prime} \mathrm{E}$ and $36^{\circ} 3^{\prime}-36^{\circ} 5^{\prime} \mathrm{N}$ and covers an area of 3400 ha.

Base map is selected from topographic map with 1:50,000 scale. It falls in drought-prone region of Semnan, Iran. The Damghan is located in desert margins and low rainfall, plant of crops has encountered with some difficulties. The serious problem of this area is water shortage. Most of study area soils are new alluvial sediments in period of the 4th of geology. Parent material in the Northern and Western of plain are sediments mixed with sand and gravel.

\section{MATERIALS AND METHODS}

Basically, various forms of originally collected and derived data were used in the study. The crucial data sources are topographic maps, soil maps, hydrological maps, infrastructure accessibility maps, fertility soil map, ecological requirements of the Damghan plain obtains through research results from literature review, expert opinions, local farmers and other published and

Corresponding Author: Shahram Ashraf, Department of Soil Science, Islamic Azad University, Damghan Branch, Damghan, Iran 
Table 1: Study of wheat growth cycle in the region

\begin{tabular}{lll}
\hline Plant & \multicolumn{1}{c}{ Planting to stability } & Vegetative stage
\end{tabular}

unpublished information such as agricultural statistics and soil reports, population reports, horticultural crops reports.

The methodology used for the physical land suitability analysis is a multi-criteria evaluation based on FAO land evaluation framework (FAO, 1976, 1985). The methodology consists in matching soil/land qualities against wheat needs and assigning a suitability rating to each land characteristic. In order to develop, a set of themes for evaluation and ultimately to produce a suitability map for Damghan plain, the crop requirement in terms of land qualities was reviewed (Sys et al., 1991; $\mathrm{FAO}, 1985$ ). In this research for getting, the evaluation appropriateness methods of lands under the important crops of barley in Damghan plain used the following methods include methods story, square root, the simple limits, the number and severity of limits. FAO assessment methods that can be done in the following stages:

Determine the properties of lands: The following properties are used for determine the characteristics of land:

Climatic properties: Climate including all information and data to the assessment yearly plant wheat (in a period of 10 years) used for the following characteristics; growth period, type of plant, date of planting according to information in connection with plant wheat planting stages, germination, vegetative into the anatomy, pollen and deal is determined (Table 1).

Soil properties (texture, lime and salinity, slope, drainage): After review field, soil physical, soil chemical, topography using these results for classified according to soil classification key will be done.

After classification, land units known as through interpretation of air photo and satellite images of working topography and control field of land. Then determine units and soil map units for the preparation of the land map will be used.
To determine of the land utilization requirements: This study includes the changes of climate and land requirements for use of lands under the important crop of wheat. That is separately for the one hand, climate and land on the other hand is done. There are land utilization requirements for each plant, mainly by Sys et al. (1991) in editing tables.

Match the land utilization requirements with land properties: When the land utilization requirements (physiologic needs for each plant) with land characteristics match are used FAO methods to be determine the of quality classes of lands suitability and factors limiting growth. Equations used to determine the lands index in various ways that is Storie method (Storie, 1976) and used for calculating the land Index (I) following equation:

Where:

$$
\mathrm{I}=\mathrm{A} * \mathrm{~B} / 100 * \mathrm{C} / 100 * \ldots .
$$

$\mathrm{I}=\mathrm{L}=\mathrm{Land}$ index

$\mathrm{A}, \mathrm{B}, \mathrm{C}, \ldots .=$ Rating of different factors effective on land index

The Square root method is used to calculate t of land Index (I), the equation is as:

$$
\mathrm{I}=\mathrm{R} \min * \sqrt{\mathrm{A} / 100^{*} \mathrm{~B} / 100^{*} \mathrm{C} / 100^{*} \ldots \ldots \ldots \ldots}
$$

Where:

$\mathrm{R}=$ One of the factors with minimum of rating

$\mathrm{A}, \mathrm{B}, \mathrm{C}, \ldots=$ Rating of different factors effective on land index

Determine classes of land suitability: Determine classes of land suitability for a plant based fitness indicators obtained from the Storie method and the Square root method shown in Table 2.

\section{RESULTS AND DISCUSSION}

With regarding to results were obtained from climatic properties and climatic data (Fig. 1) and climatic suitability evaluation that given by Sys et al. (1991), the climatic characteristics of region are Suitable (S) for wheat plantation (Table 3 ). The results showed that the soils on the basis of soil taxonomy system were classified as Entisols and Aridisols (Table 4). The results according to 
Res. J. Biol. Sci., 5 (8): 548-552, 2010

Table 3: Rating of climatic factors for wheat crop in Damghan plain

\begin{tabular}{llccc}
\hline Climatic factors & Properties & Simple limits & No. and severity of limits & Parametric rating \\
\hline Mean temp. of growth & 11.42 & $\mathrm{~S} 2$ & 2 & 77.75 \\
Mean temp. of vegetative stage & 7.120 & $\mathrm{~S} 1$ & 1 & 90.60 \\
Mean temp. of flowering stage & 17.97 & $\mathrm{~S} 1$ & 0 & 97.48 \\
Mean temp. for ripening stage & 23.13 & $\mathrm{~S} 1$ & 0 & 99.45 \\
Mean daily min temp. coldest month & 7.850 & $\mathrm{~S} 1$ & & 100.00 \\
Mean daily max temp. coldest month & -1.075 & & & 77.75 \\
Climatic index & Storie & & & 77.75 \\
Climatic rating & Square root & & & 86.65 \\
Claimatic classes & Storie/square root & & $\mathrm{S} 2$ & $\mathrm{~S} 1$ \\
\hline
\end{tabular}

Table 4: Study of soil classification in the region

\begin{tabular}{lclll}
\hline Physiographic & Land units & Taxonomy USDA soil family & Subgroups & Order \\
\hline Old plateau & 1.1 & Coarse loamy, mixed, thermic & Typic torriorthents & Entisols \\
& 1.2 & Coarse loamy, mixed, thermic & Typic torriorthents & Entisols \\
Alluvium plain & 2.1 & Fine loamy, mixed, thermic & Typic torriorthents & Entisols \\
Low land & 3.1 & fine loamy, mixed, thermic & Typic aquisalids & Aridisols \\
\hline
\end{tabular}

Table 5: Quantities of land index properties and factor rating in land unit for wheat

\begin{tabular}{|c|c|c|c|c|c|c|c|c|c|c|}
\hline$\underline{\text { Land units }}$ & Microrelif & Rating & Drainage & Rating & $\begin{array}{l}\text { Texture- } \\
\text { structure }\end{array}$ & Rating & Gravel (\%) & Rating & Depth $(\mathrm{cm})$ & Rating \\
\hline 1.1 & $5-15$ & 90 & $>3$ & 98.0 & SL & 75.0 & $>55$ & 12.5 & $60-90$ & 90.0 \\
\hline 1.2 & $30-60$ & 50 & $>3$ & 98.0 & SL & 75.0 & $>55$ & 12.5 & $60-90$ & 85.0 \\
\hline 2.1 & $5-15$ & 90 & $>3$ & 97.5 & CL & 97.5 & $0-3$ & 95.0 & $>90$ & 97.5 \\
\hline 3.1 & $5-15$ & 90 & $1-2$ & 70.0 & $\mathrm{CL}$ & 95.0 & $0-3$ & 95.0 & $>90$ & 97.5 \\
\hline $\mathrm{CaCO}_{3}(\%)$ & Rating & \multicolumn{2}{|c|}{$\mathrm{CaSO}_{4}$} & Rating & $\mathrm{pH}$ & Rating & $\mathrm{EC}$ & Rating & ESP & Rating \\
\hline 29.65 & 88.50 & \multicolumn{2}{|c|}{6.35} & 80.95 & 7.88 & 93 & 60.35 & 12.5 & 44.00 & 42.0 \\
\hline 88.75 & 88.75 & \multicolumn{2}{|c|}{6.35} & 80.95 & 7.88 & 93 & 60.50 & 12.5 & 44.00 & 42.0 \\
\hline 34.65 & 83.50 & \multicolumn{2}{|c|}{11.00} & 58.00 & 8.10 & 86 & 74.50 & 12.5 & 41.48 & 47.0 \\
\hline 30.94 & 87.71 & \multicolumn{2}{|c|}{9.11} & 64.50 & 7.88 & 93 & 109.88 & 12.5 & 49.30 & 12.5 \\
\hline
\end{tabular}

R: Rating

Table 6: Comparison of land suitability evaluation methods in land units

\begin{tabular}{lcccc}
\multicolumn{2}{c}{ for wheat } & & & \\
\hline Land unit & $\begin{array}{c}\text { The simple } \\
\text { limits }\end{array}$ & $\begin{array}{c}\text { No. and } \\
\text { severity of limits }\end{array}$ & Storie & Square root \\
\hline 1.1 & N2 & N2 & N2 & N2 \\
1.2 & N2 & N2 & N2 & N2 \\
2.1 & N2 & N2 & N2 & N2 \\
3.1 & N2 & N2 & N2 & N2 \\
\hline
\end{tabular}

description of soil profiles and physical and chemical analysis of soil samples showed the level of gravel, Exchangeable Sodium Percentage (ESP) and salinity in land units 1.1, 1.2 and Exchangeable Sodium Percentage (ESP) and salinity in land units $2.1,3.1$ were the most limitation factors for wheat plantation in this region (Table 5). Therefore, these parameters will impress the yield value of wheat plant. The comparison of qualitative land suitability methods results for wheat crop plant (Table 6) indicates that the range of changes of classes in different land units according to Simple limitation method, limitation regarding number and intensity method, Storie parametric method and Root square parametric method are $\mathrm{N} 2, \mathrm{~N} 2, \mathrm{~N} 2, \mathrm{~N} 2$, respectively including the qualitative land units map of the region obtained from different methods (Fig. 2). The ultimate evaluation of the qualitative land suitability for wheat using simple limitation and number and severity of limits and square root and

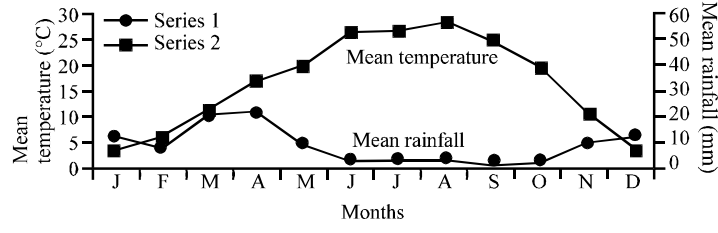

Fig. 1: Regional umbrothermic figure

Land suitability map for wheat scale: $1 / 50,000$

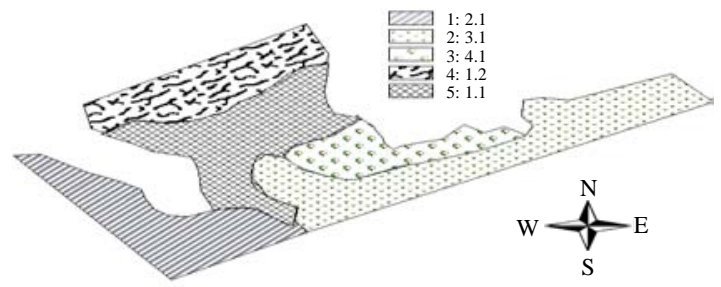

Fig. 2: Map of land units in Damghan plain for wheat

parametric methods are shown in Table 6. The results of the physical evaluation showed a close correlation between all of the methods (the results were N2). Jafarzadeh and Abbasi (2006) indicates that simple limits, number and severity of limits show similar suitability classes which confirms the previous findings for several 
crops by other researchers. However in many cases, the use of Parametric methods, especially the Square root method revealed to be more realistic in showing the distinguished suitability classes in many cases. Assessment results in two methods, Limited and Parametric had close and only in the Parametric method have the class of lands much less to simple limit that is because many interactions between land characteristics for estimate of the land index.

In Parametric method soil depth and gravel and soil texture as composed index of soil of all three characteristics are evaluated but a simple limit method each parameter can be evaluated separately. Behzad et al. (2009) showed that from the methods used, i.e., Simple limitation and Storie and Square root methods, the latter (Square root methods) produced more realistic results for barley, wheat and alfalfa on the existing conditions of the region. Limiting factors in different crop yield in the region along with climatic variables included soil physical properties, especially its carbonate contents, soil salinity and drainage. Yasmina et al. (2001) showed by the use of the Parametric methods much of the croplands of the region were in critical conditions the most limiting factors of which including soil texture, soil depth and drainage. The main crops of the area were wheat, barely, pea, bean and onion. Al-Areba et al. (2007) showed the evaluation class suitable to permanently not suitable for barley and wheat in Essaouira province, Morocco.

This was due to the different condition that the crops require for their developments in the local area in question. Generally, the most important limiting factors in wheat productions in the Damghan plain included climate (deficit rainfall during the growing season) and physical properties of the soil especially gravel, Exchangeable Sodium Percentage (ESP) and salinity in land unit 1.1, 1.2 and Exchangeable Sodium Percentage (ESP) and salinity in land unit 2.1, 3.1. Albaji et al. (2009) showed the indexes obtained for alfalfa, wheat and barley were higher on comparison to that developed for maize. Shahbzi and Jafarzadeh (2004) suggested that the Parametric method based on square root is more realistic than others.

\section{CONCLUSION}

The results showed that the methods used including simple limitation, number and severity of limits and parametric methods (Storie and Square root methods), on the region had close correlation. The results of this study showed that climatic characteristics of the region were suitable for wheat plantation on the all methods. The all parts of the study area were classified as non-suitable for investigated wheat crop plant due to physical and chemical soil parameters on the all methods. Furthermore, the most limiting chemical factors being considered in this area were soil salinity and alkalinity. The qualitative land suitability evaluation assists decision makers in ensuring that lands are used according to their capacities to satisfy human needs for present and future generations thus, sustaining ecological and economic productivity of natural resources. On the other hand, the soil maps for agricultural suitability designed in this research can be helpful in carrying out the management processes.

\section{REFERENCES}

Al-Areba, A., A.S.A. Salami, A. Ouafae, B. Rigobert, D. Laura and G. Gebremeskel et al., 2007. Land evaluation in essaouira province Morocco. Proceedings of 27 th Professional Course on Geomatics and Natural Resources Evaluation, Nov. 6, 2006-Jun. 22, 2007, Foreign Affairs, Istituto Agronomico Per L'oltremare, pp: 1-213.

Albaji, M., A.A. Naseri, P.P. Apan and S.B. Nasab, 2009. Qualitative evaluation of land suitability for principal crops in the West Shoush Plain, Southwest Iran. Bulg. J. Agric. Sci., 15: 135-145.

Behzad, M., M. Albaji, P. Papan, S.B. Nasab, A.A. Naseri and A. Bavi, 2009. Qualitative evaluation of land suitability for principal crops in the Gargar Region, Khuzestan Province, Southwest Iran. Asian J. Plant Sci., 8: 28-34.

Breeuwsma, A., J.H.M. Wosten, J.J. Vleeshoumer, A.M. van Slobbe and J. Bouma, 1986. Derivation of land qualities to assess environmental problems from soil survey. Soil Sci. Sco. Am. J., 50: 186-190.

Burrough, P.A., 1996. Opportunity and Limitation of GISBased Modeling of Solute Transport at the Regionl Scale. In: Aplication of GIS to the Modeling of NonPoint Source Pollutants in the Vadose Zone, Corwin, D.L. and K. Loage (Eds.). SSSA., Madison, WI.

FAO, 1976. A framework for land evaluation. Food and Agriculture Organization of the United Nations, Soil Bulletin No. 32. Rome. http://www.fao.org/docrep/x $5310 \mathrm{e} / \mathrm{x} 5310 \mathrm{e} 00 . \mathrm{htm}$.

FAO, 1985. Guidelines: Land evaluation for irrigated agriculture. FAO Soils Bulletin, No. 55, FAO, Rome. http://www.fao.org/docrep/x5648e/x5648e00.htm.

Jafarzadeh, A.A. and G. Abbasi, 2006. Qualitative land suitability evaluation for the growth of onion, potato, maize and alfalfa on soils of the Khalat pushan research station. Biologia, 61: S349-S352.

Shahbzi, F. and A.A. Jafarzadeh, 2004. Qualitative evaluation of land suitability Khusheh-Mehr region of Bonab in East Azarbaijan for wheat, barley, alfalfa, onion, sugarbeet and maize. J. Agric. Sci., 14: 69-86. 
Storie, R.E., 1976. Storie Index Rating. Division of Agricultural Science, University of California, Berkeley.

Sys, C., E. Vanranst and J. Debvay, 1991. Land Evaluation, Part: III. General Adminstration for Development Coopration Agriculture, Brussels, Belgium.
Yasmina, A., A. Moulay, A.M. Najmia, B. Enrico and B. Yasmina et al., 2001. Land evaluation in the province of ben slimane, Morocco. Proceedings of 21 st Course Professional Master Remote Sensing and Natural Resource Evaluation, Nov. 10, 2000-June 22, 2001, Foreign Affairs, Istituto Agronomico Per L'oltremare, Italy, pp: 1-148. 